\title{
The Body Image Profile of Student of Universitas Negeri Padang in Terms of Their Admission
}

\author{
Verlanda Yuca ${ }^{*}$, Puji Gusri Handayani², Daharnis Daharnis ${ }^{3}$, Zadrian Ardi ${ }^{4}$, Elrisfa Magistarina $^{5}$, \\ Ifdil $^{6}$, Frischa Meivilona Yendi ${ }^{7}$ \\ ${ }^{1234567}$ Guidance and Counseling, Faculty of Education,Universitas Negeri Padang, Indonesia
}

\begin{abstract}
The most basic human needs are physiological needs. Human physical appearance, as a part of physiological needs, is considered as an essential part of people's lives. That essential part determines the formation of body image (self-image) in the community. Body image is a mental picture of the state of the human body. That is how people give values of the size and shape of their bodies or others' opinions about them. This study aims to describe the body image of students in terms of their admission. This study uses a quantitative approach to the type of descriptive research. The sampling technique used Simple Random Sampling on 161 students of Universitas Negeri Padang. Data collection techniques through questionnaires with descriptive analysis. The research findings show that a picture of the body image condition of UNP students on average is in the medium category with the reliability of 0.824 .
\end{abstract}

Keywords

Body image; Students

Article Received: 20 September 2020, Revised: 30 November 2020, Accepted: 18 December 2020

\section{Introduction}

Maslow's Hierarchy of Needs consists of eight (8) levels of needs. Namely, physiological, safety, love and belongingness, esteem needs, cognitive needs, aesthetics, self-actualization, and transcendence (Maslow \& Lewis, 1987; McLeod, 2007). Based on Maslow's Hierarchy of Needs, one of the human needs is physiological needs, which are the most basic and are more related to physical needs and which have great potential to achieve the next needs.

The rapid development in the era of industrialization and the culture of consumerism across the world, making humans form the body image and ideal body standards - human physical appearance considered as an essential part of life in this era. Body image is a mental picture of the state of the human body. That is how people give values of the size and shape of their bodies or others' opinions about them.

Body Image is an aspect related to psychological development and interpersonal relationships in adolescents (Denich \& Ifdil, 2015). Both men and women are paying more attention to their physical appearance compared to other aspects of human life (Gunarsa, 1991, 2008; Winarni, 2015). One of the factors that influence the development of a person's body image is gender (T. F. Cash, 1994; T. F. Cash, Melnyk, \& Hrabosky, 2004) (Phares, Steinberg, \& Thompson, 2004). Body dissatisfaction will be more common in women than in men (T. F. Cash, 1994). In general, women are more or less satisfied with their bodies and have a negative body image. Women are usually more critical of their bodies both as a whole and in certain parts of their body than men. Poor body image perception is often associated with feelings of being overweight, especially in women. A man, pay more attention to muscle mass when considering their body image. Generally a bad body image can cause a constant diet and a diet that is temporary, obesity, and eating disorders and can cause low self-esteem, depression, anxiety and overall emotional distress (Denich \& Ifdil, 2015; Ifdil, Denich, \& Ilyas, 2017).

In the range of $40-70 \%$ of teenage girls are dissatisfied with two or more aspects of their body; substantially in the middle or lower body, such as hips, abdomen and thighs. In the range of $50-80 \%$ teenage girls want to be slim and go on a diet that varies from $20 \%$ to $60 \%$ (Kennedy \& Markula, 2011; Mansfield). A man also wants to 
avoid fat, flabby body shapes, but among men who are not satisfied with the weight and shape try to gain weight to develop upper arms, chest and shoulders (Denich \& Ifdil, 2015). Body image formation is the result of reciprocal relationships between physical processes and individual behaviour that occur in the cognitive and affective areas (T. F. Cash, 2002; T. F. Cash \& Pruzinsky, 2002) (Grogan, 2006).

Based on the previous definition, it concluded that the body image is a feeling, experience, attitude and evaluation that a person has about his body including the shape and the size of the body, which leads to a positive and negative physical appearance. On the one hand, a positive body image can be described as a good perception of one's body shape, appreciates the body and appreciate the uniqueness of the body, refuses to think unreasonably, feels comfortable and confident with the body it has (Dede et al., 2007). On the other hand, a negative body image is a distortion of perception of one's body shape, thinking that other people are more attractive, feeling embarrassed, anxious, strange and uncomfortable about the size or shape of their body (Dede, et al., 2007). Gender, family, and interpersonal relationships are factors that influence body image (Henggaryadi, 2012; Nahdiyah, 2015).

Based on the previous explanation, there is much urgency in the body image of the community, especially in the development of adolescents. The purpose of this study is to describe the condition of the body image of students of Universitas Negeri Padang.

Table 1. Overall Picture of the Students' Body Image $(\mathrm{N}=161)$

\section{Method}

This research used a quantitative approach with a comparative descriptive design. One hundred sixty-one respondents participated in this research that comes from various faculties at Universitas Negeri Padang. The instrument used Multidimensional Body Self Relations Questionnaire (MBSRQ) (Brytek-Matera, Donini, Krupa, Poggiogalle, \& Hay, 2015; T. F. Cash, 1990) (T. Cash, 2000), and the data collected was processed descriptively and the analysis of variance test (One-Way ANOVA) (Field, 2013; Kariadinata, 2015).

\section{Results and Discussion}

The results of this study describe the overall body image of students. The aspects in this study consist of an assessment of the overall appearance of the body, a fundamental view of selfappearance, individual awareness of gaining weight and limiting eating patterns, and measuring individual satisfaction with specific body parts and overall from top to bottom. Expose the data referred to, stated as follows:

\section{Result}

\section{Overview of Body Image of The students of Universitas Negeri Padang}

\section{Data on Body Image of Universitas Negeri Padang's Students show in Table 1.}

\begin{tabular}{cccc}
\hline Category & Score & F & $\%$ \\
\hline Very high & $>=252$ & 6 & 3,72 \\
High & $230-251$ & 46 & 28,57 \\
Medium & $208-229$ & 65 & 40,37 \\
Low & $186-207$ & 41 & 25,46 \\
Very Low & $<=164$ & 3 & 1,86 \\
& Total & 161 & 100 \\
\hline
\end{tabular}

Table 1 shows that the description of the body image of the student of Universitas Negeri Padang is still far from what expected. In general, the students' body image is in the medium category, with 65 students or $40.37 \%$. Then, those included in the high and low categories had not so much 
different numbers, namely $28.57 \%$ for the high category and $25.46 \%$ for the low category.

Furthermore, in a general body image study, the body image of students from the college entry point will also be reviewed. Universitas Negeri Padang has three (3) admissions system, namely: Seleksi Bersama Masuk Perguruan Tinggi Negeri
(SBMPTN), Seleksi Nasional Masuk Perguruan Tinggi Negeri (SNMPTN) and an exam that conduct by the university or called as Jalur Mandiri. The researcher revealed the picture of the student's body image through the entrance path as described in the following table.

Table 2. Overview of body image based on the admission system

\begin{tabular}{ccccccccc}
\hline Kategori & Skor & \multicolumn{2}{c}{ SBMPTN } & \multicolumn{2}{c}{ SNMPTN } & \multicolumn{2}{c}{ Mandiri } & Jumlah \\
\hline & & F & \% & F & \% & F & \% & \\
Very High & $>=252$ & 3 & 4,29 & 2 & 4 & 1 & 2,44 & 6 \\
High & $230-251$ & 19 & 27,14 & 16 & 32 & 11 & 26,83 & 46 \\
Medium & $208-229$ & 30 & 42,86 & 19 & 38 & 16 & 39,02 & 65 \\
Low & $186-207$ & 17 & 24,29 & 12 & 24 & 12 & 29,27 & 41 \\
Very Low & $<=164$ & 1 & 1,43 & 1 & 2 & 1 & 2,44 & 3 \\
& & 70 & 100 & 50 & 100 & 41 & 100 & 161 \\
\hline
\end{tabular}

Further studies related to the body image of students are viewed from the admission systems as described in Table 2. From the data obtained, 70 students were entering via SBMPTN, 50 SNMPTN students, and the rest from the Jalur Mandiri. In general, student body image shows in the medium category for the three admission systems.
Analysis of the results of the One-way ANOVA test found several explanations of the comparative test of the mean difference between groups of entry points and the variability of data within groups (between) and between groups (between) (Field, 2013; Winarsunu, 2002). The results of the One-way ANOVA analysis shows in the following tables.

Table 3. Homogeneity

\begin{tabular}{cccccc}
\hline & Test of Homogeneity of Variances & & \\
\hline Body Image & & & & & \\
\hline Levene Statistic & df1 & 2 & df 2 & 158 & \\
\hline
\end{tabular}

The homogeneity variance test conducted with the Levene Test; this test used to determine whether the variants of the three groups were the same (Kariadinata, 2015; Setyawarno, 2016). The qualifying data is when the same variant or subject comes from a homogeneous group.
Homogeneity test of the three variants (SBMPTN, SNMPTN, and Jalur Mandiri) is the same as the probability value (significance) is 0.870 greater than 0.05 .

Table 4. One-way ANOVA

\begin{tabular}{lcrrrr}
\hline \multicolumn{7}{c}{ One-way ANOVA } & & & \\
\hline Body Image & Sum of Squares & df & Mean Square & F & Sig. \\
Between Groups & 100,766 & 2 & 50,383 &, 152 &, 859 \\
Within Groups & 52205,135 & 158 & 330,412 & & \\
Total & 52305,901 & 160 & & \\
\hline
\end{tabular}


In One-way ANOVA, it found that there was no difference between the average scores of the SBMPTN, SNMPTN, and Jalur Mandiri. The Table 4 shows that comparison between the calculated F-value and the $\mathrm{F}$ table value because the $\mathrm{F}$ calculated $\leq \mathrm{F}$ table $(0.152 \leq 3.053)$, it can be concluded that there is no difference between the average value of the group.

\section{Discussion}

Body Image is a proper appraisal of one's body, appreciating natural form and feeling joy and acceptance of her body uniquely, refusing to think unreasonably, feeling comfortable and confident with one's body (Dede, et al., 2007; Hardjana, 2003). Students' views on themselves affect how students interact in various environments (Ifdil, et al., 2017; Pasaribu, 2016). For example, in the university environment, where every student is able to enrol in the University through several admission.

The selection process of new students conducted in every university, so that prospective students who will enter the university have excellent quality. Therefore, each institution, especially higher institution, carries out several stages of new student selection (Nurhasanah, Purwati, \& Ahmad, 2018; Suwena, 2017). Universitas Negeri Padang (UNP) is one of the higher institutions that become a destination for students who have completed their secondary school education. The process of admitting new students through three channels namely, SNMPTN, SBMPTN, and Mandiri (Asriani \& Kustiawan, 2017; D. Lestari, Anis, \& Khaeruddin, 2019) (S. Lestari \& Lumbanraja, 2018). Selection activities to obtain superior prospective students by giving opportunities to the broader community to become students and contribute to improving the quality of education (Daharnis \& Ardi, 2016).

From the three different way of the admission, SNMPTN expected to have the most superior quality, and usually, the students will have a good impression of themselves. This expectation arises because in the admission stage of new students with SNMPTN are students who pass the national selection based on academic achievement on the report card grades each semester (Handayani \& Yuca, 2018; Saputra, Suwena, \& Tripalupi, 2016) (Suwena, 2017). However, this is not the case with the results of the study, which says that the average body image of students from the three admission systems for college students is in the medium category. So, the level of body image of the students is on the same level, which is in the medium category.

The three different way of admission has a different quality of students. In SNMPTN, students expected to have competent competencies because they recruited using their grade in their previous school (Chapman, 1981; Ley \& Young, 1998) (Zimmerman, 2014). Otherwise, students who were enrolled through Jalur Mandiri using the criteria set by the university and usually they take Jalur Mandiri because they failed SNMPTN and SBMPTN (Jones-Schenk \& Harper, 2014; Oates, 1997) (Sedlacek, 2003).

In a further study related to body image, it found that there are no differences in body image of the students in terms of the admission systems revealed from the results of this study enabled the need for scientific studies related to body image. How a person's views and understanding of him physically, psychologically, and interpersonal relationships (Denich \& Ifdil, 2015). Thus, the three different way of admission is not influencing the students in their interaction.

Since the three different way of admissions does not affect the body image of the students, the study will continue to investigate another aspect that might influence the body image. For example, gender, perception, mass media, interpersonal relationship and sociocultural (Cafri, Yamamiya, Brannick, \& Thompson, 2005). Those aspects believed to give impact to the way students' see and value their self.

Body image formed from three aspects, such as cognitive, perceptual and behavior. Cognitive aspect explains how people think about their performance. The perceptual aspect defines the way people value their self. While, according to 
behavior, mention that how people treat their body, like doing some makeup, covering the size or shape of the body, or avoid seeing others body (Sulistiya, Sugiharto, \& Mulawarman, 2017). These conditions will build their self-concept, even positively or negatively. The negative body image can transform into a positive body image so that people are able to values and see their self. This condition revealed from the study about increasing students' body image using cognitive restructuring in CBT (Cognitive Behavior Therapy) group counseling (Santos-Pinto \& Sobel, 2005; Sulistiya, et al., 2017) (Webster \& Tiggemann, 2003).

\section{Conclusion}

Based on data obtained from respondents, it shows that students from various admission systems have the same body image, meaning that the entrance lane does not affect the student body image in understanding themselves and their environment. It expected that students have a high body image to create a pleasant and superior personality and have good social interaction on campus and outside. The most significant demand is for teaching staff such as lecturers and especially for counsellors in the counseling department who can create and develop a positive body image of each student.

\section{References}

[1] Asriani, E., \& Kustiawan, E. (2017). Analisis Kemandirian Belajar Mahasiswa Universitas Bangka Belitung (UBB) Berdasarkan Tiga Jalur Penerimaan. Paper presented at the Seminar Nasional Riset Inovatif.

[2] Brytek-Matera, A., Donini, L. M., Krupa, M., Poggiogalle, E., \& Hay, P. (2015). Orthorexia nervosa and self-attitudinal aspects of body image in female and male university students. Journal of Eating Disorders, 3(1), 2.

[3] Cafri, G., Yamamiya, Y., Brannick, M., \& Thompson, J. K. (2005). The influence of sociocultural factors on body image: A meta-analysis. Clinical Psychology: science and practice, 12(4), 421-433.

[4] Cash, T. (2000). The multidimensional body-self relations questionnaire users' manual. Available from the author at $w w w$. body-images. com.

[5] Cash, T. F. (1990). The multidimensional body-self relations questionnaire. Unpublished test manual, Old Dominion University, Norfolk, VA.

[6] Cash, T. F. (1994). Body-image attitudes: Evaluation, investment, and affect. Perceptual and Motor skills, 78(3_suppl), 1168-1170.

[7] Cash, T. F. (2002). The situational inventory of body-image dysphoria: Psychometric evidence and development of a short form. International Journal of eating disorders, 32(3), 362-366.

[8] Cash, T. F., Melnyk, S. E., \& Hrabosky, J. I. (2004). The assessment of body image investment: An extensive revision of the Appearance Schemas Inventory. International Journal of eating disorders, 35(3), 305-316.

[9] Cash, T. F., \& Pruzinsky, T. (2002). Future challenges for body image theory, research, and clinical practice. Body image: A handbook of theory, research, and clinical practice, 509-516.

[10] Chapman, D. W. (1981). A model of student college choice. The Journal of Higher Education, 52(5), 490-505.

[11] Daharnis, D., \& Ardi, Z. (2016). The compatibility student choice of university majoring; A preliminary studies. GUIDENA: Jurnal Ilmu Pendidikan, Psikologi, Bimbingan Dan Konseling, 6(1), 101-109. 
[12] Dede, D. S., Yavuz, B., Yavuz, B. B., Cankurtaran, M., Halil, M., Ulger, Z., et al. (2007). Assessment of endothelial function in Alzheimer's disease: is Alzheimer's disease a vascular disease? Journal of the American Geriatrics Society, 55(10), 16131617.

[13] Denich, A. U., \& Ifdil, I. (2015). Konsep Body Image Remaja Putri. Jurnal Konseling Dan Pendidikan, 3(2), 55-61.

[14] Field, A. (2013). Discovering statistics using IBM SPSS statistics: sage.

[15] Grogan, S. (2006). Body image and health: Contemporary perspectives. Journal of health psychology, 11(4), 523-530.

[16] Gunarsa, S. D. (1991). Psikologi praktis: anak, remaja dan keluarga: BPK Gunung Mulia.

[17] Gunarsa, S. D. (2008). Psikologi perkembangan anak dan remaja: $\mathrm{BPK}$ Gunung Mulia.

[18] Handayani, P. G., \& Yuca, V. (2018). Fenomena Culture Shock Pada Mahasiswa Perantauan Tingkat 1 Universitas Negeri Padang. Jurnal Konseling Dan Pendidikan, 6(3), 198-204.

[19] Hardjana, A. M. (2003). Komunikasi interpersonal dan intrapersonal: Kanisius.

[20] Henggaryadi, G. (2012). Hubungan antara body image dengan harga diri pada remaja pria yang mengikuti latihan fitness/kebugaran.

[21] Ifdil, I., Denich, A. U., \& Ilyas, A. (2017). Hubungan body image dengan kepercayaan diri remaja putri. Jurnal Kajian Bimbingan dan Konseling, 2(3), 107-113.
[22] Jones-Schenk, J., \& Harper, M. G. (2014). Emotional intelligence: An admission criterion alternative to cumulative grade point averages for prelicensure students. Nurse Education Today, 34(3), 413-420.

[23] Kariadinata, R. (2015). Dasar-dasar statistik pendidikan: CV Pustaka Setia.

[24] Kennedy, E., \& Markula, P. (2011). Women and exercise: The body, health and consumerism (Vol. 5): Routledge.

[25] Lestari, D., Anis, H., \& Khaeruddin, K. (2019). Analisis Hasil Belajar Mahasiswa Jurusan Fisika Berdasarkan Jalur Masuk (SNMPTN, SBMPTN dan Mandiri) Universitas Negeri Makassar. Jurnal Sains dan Pendidikan Fisika, 14(3).

[26] Lestari, S., \& Lumbanraja, N. M. (2018). Gambaran Body Image Sales Promotion Girl Otomotif. Jurnal Sains Psikologi, 7(2), 155161.

[27] Ley, K., \& Young, D. B. (1998). Selfregulation behaviors in underprepared (developmental) and regular admission college students. Contemporary Educational Psychology, 23(1), 42-64.

[28] Mansfield, L. Fit, Fat and Feminine. Women and Exercise: The Body, Health and Consumerism, 5, 81.

[29] Maslow, A., \& Lewis, K. (1987). Maslow's hierarchy of needs. Salenger Incorporated, 14, 987.

[30] McLeod, S. (2007). Maslow's hierarchy of needs. Simply psychology, 1, 1-8.

[31] Nahdiyah, I. (2015). Hubungan antara body image dengan kepuasan hidup pada remaja yang mengalami obesitas di Komunitas KAGUMI (Ikatan Wanita Gemuk Indonesia). 
Universitas Islam Negeri Maulana Malik Ibrahim Malang.

[32] Nurhasanah, N., Purwati, P., \& Ahmad, H. (2018). Pengaruh Sistem Seleksi Masuk Perguruan Tinggi Terhadap Indeks Prestasi Mahasiswa Jurusan Pendidikan Matematika Universitas Papua (UNIPA). Prosiding, $3(1)$.

[33] Oates, L. C. (1997). Beating the odds: Reading strategies of law students admitted through alternative admissions programs. Iowa L. Rev., 83, 139.

[34] Pasaribu, S. (2016). Hubungan Konsep Diri Dan Dukungan Sosial Teman Sebaya Dengan Interaksi Sosial Mahasiswa. Analitika, 8(1), 64-78.

[35] Phares, V., Steinberg, A. R., \& Thompson, J. K. (2004). Gender differences in peer and parental influences: Body image disturbance, self-worth, and psychological functioning in preadolescent children. Journal of Youth and Adolescence, 33(5), 421-429.

[36] Santos-Pinto, L., \& Sobel, J. (2005). A model of positive self-image in subjective assessments. American Economic Review, 95(5), 1386-1402.

[37] Saputra, K. E. A., Suwena, K. R., \& Tripalupi, L. E. (2016). Studi komparatif prestasi belajar mahasiswa jurusan pendidikan ekonomi ditinjau dari jalur penerimaan mahasiswa baru tahun 2011. Jurnal Pendidikan Ekonomi Undiksha, 6(1).

[38] Sedlacek, W. E. (2003). Alternative admissions and scholarship selection measures in higher education. Measurement and Evaluation in Counseling and Development, 35(4), 263-272.

[39] Setyawarno, D. (2016). Panduan statistik terapan untuk penelitian pendidikan.
Panduan Statistik Terapan untuk Penelitian Pendidikan, 1-116.

[40] Sulistiya, E., Sugiharto, D. Y. P., \& Mulawarman, M. (2017). Dampak Konseling Kelompok Cognitive Behavior Therapy (CBT) Teknik Cognitive Restructuring untuk Meningkatkan Body Image. Jurnal Bimbingan Konseling, 6(2), 135-140.

[41] Suwena, K. R. (2017). Jalur Penerimaan Mahasiswa Baru Bukan Penentu Prestasi Belajar Mahasiswa. Ekuitas: Jurnal Pendidikan Ekonomi, 5(2), 1-10.

[42] Webster, J., \& Tiggemann, M. (2003). The relationship between women's body satisfaction and self-image across the life span: The role of cognitive control. The journal of genetic psychology, 164(2), 241252.

[43] Winarni, R. W. (2015). Representasi Kecantikan Perempuan dalam Iklan. Deiksis, 2(02), 134-152.

[44] Winarsunu, T. (2002). Statistik dalam penelitian psikologi dan pendidikan: Penerbitan Universitas Muhammadiyah Malang.

[45] Zimmerman, S. D. (2014). The returns to college admission for academically marginal students. Journal of Labor Economics, 32(4), 711-754. 